\title{
The use of electrotechnical equipment for food production wastewater treatment
}

\begin{abstract}
The wastewater ecological danger has been established on the example of a meat processing enterprise, systematic exceedances of normative maximum permissible concentrations of contaminants and unpredictable fluctuations of their values have been registered. The design of thesewage treatment electroflotocoagulation module is developed. Wastewaters from a dairy plant, a bakery, a distillery and a sugar plant were treated at the electrotechnical complex. Analytical dependencies are established to determine the energy consumption for counteraction of potential emergencies.

Streszczenie. Zagrożenie ekologiczne ścieków określono na przykładzie zakładu przetwórstwa mięsnego, zarejestrowano systematyczne przekraczanie normatywnych maksymalnych dopuszczalnych stężeń zanieczyszczeń oraz nieprzewidywalne wahania ich wartości. Opracowuje się projekt modułu elektroflotokoagulacji do oczyszczania ścieków. W kompleksie elektrotechnicznym oczyszczano ścieki z mleczarni, piekarni, gorzelni i cukrowni. Ustalono zależności analityczne w celu określenia zużycia energii na przeciwdziałanie potencjalnym awariom. (Wykorzystanie urządzeń elektrycznych do oczyszczania ścieków z produkcji spożywczej)
\end{abstract}

Key words: emergencies, electrophlotocoagulation, electrodialysis, environmental safety.

Słowa kluczowe: oczyszczanie ścieków, elektrodializa

\section{Introduction}

In terms of pathogens and toxic substances emissions into the air and water environment, their mass and diversity, Ukraine is approaching the industrially developed countries [1]. Thus, during 2017, 166 emergencies were registered, which according to the National Classifier "Classification of Emergency" DK 019: 2010 were distributed (according to the State Emergency Service of Ukraine) distributed as follows: man-made - 50; of natural character - 107; social nature -9 .

At the same time, an emergency in the production can cause the action of technogenic emergencies, which is especially relevant for food companies, as the volume of effluents from such spillways is significant $\left(100 \mathrm{~m}^{3} /\right.$ day $4,000 \mathrm{~m}^{3}$ / day). Emergencies can cause environmental pollution by organic and inorganic compounds, including potential catastrophic consequences of a transboundary nature $[1,2]$. At the same time, the authors did not offer design schemes for water treatment systems to counteract the volleys of pollutants.

Accordingly, the feasibility study of the electrical equipment use for wastewater treatment of food production with the ability to counteract potential emergencies is an urgent scientific and practical task.

\section{Substantiation of research tasks.}

The choice of electrotechnical treatment methods and means for effluents of food industrial facilities and parameters of electrical equipment was performed on the basis of DBN B.2.5-75: 2013 "Sewerage external networks and structures. Basic design provisions", analysis of research by other authors [1] and own theoretical and practical developments. At the same time, in this regulatory document and studies [3, 4], the possibility of counteracting emergencies and choosing the appropriate list of equipment is not indicated.

Exploratory research of effluent quality indicators was carried out at a meat processing plant, where the values of two key contaminants of wastewater were recorded such as: suspended particles (maximum permissible concentration (MPC) - $1000 \mathrm{mg} / \mathrm{I}$ ) and ammonium nitrogen (MPC - $35 \mathrm{mg} / \mathrm{I}$ ).

During the month, the average daily values of contaminants, which are typical for the effluents of the meat processing plant, were recorded. Analysis of pollutant values showed that they are within the following limits: suspended particles - 987 - 4712, $\mathrm{mg} / \mathrm{l}$, ammonium nitrogen - 31 - 62, mg/l.

However, in all samplings (except for one research day on the quality indicator "suspended particles"), the excess of MPC was recorded even without the impact of emergencies. At the same time, it is advisable to take into account the potential effect of emergency, as the water treatment equipment of the regular nomenclature is able to work only within the limits specified in the draft proposal.

To do this, first, in the developed system of electrotechnical complex efficient operation for food production it is necessary to integrate the blocks of intelligent control system $[6,7,8]$, which will be solving the problem of the effluents supply / non-supply to treatment plants, the state of effluents quality assessment which come for purification and their quality after purification, the calculation of additional resource costs to counter emergencies of various kinds, etc. At the same time, the authors of these works did not take into account the possibility of the ecological and energy efficiency comprehensive assessment for the work of the corresponding equipment.

Secondly, it is necessary to include in treatment facilities electrotechnical units whose task will be to combat volley emissions in case of emergencies by two-stage removal of pollutants, based on the nature of the latter [1]:

1. removal of suspended particles and colloids,

2. purification from molecularly dissolved and iondissociated pollutants.

The first stage (partially acting on molecular compounds) will be implemented using electroflotocoagulation [5], the second - on the basis of electrodialysis processes. It should be noted that the method of electrochemical equipment separate use proposed by the authors does not provide an opportunity to counteract emergencies.

However, analyzing the key pollutants of the studied enterprises and the basic methods of wastewater treatment, we can conclude that at most industrial facilities of food production the task of the electrodialysis unit will be the removal of chlorides $[9,10]$ (the concentration of the latter was determined according to the methods presented in ISO 10304). Also, given the presence of dissolved organic pollutants in such effluents, it is necessary to control the 
integrated indicator - chemical oxygen demand (COD) (the concentration of the latter was determined according to the methods presented in ISO 15705: 2002).

\section{Experimental equipment}

One of the modern methods of wastewater treatment, which belongs to the physico-chemical, is the electrotreatment by the combination of electroflotation and electrocoagulation when the power management [11, 12]. That is why the study of meat processing enterprises effluent treatment was carried out on the developed physical models of electroflotocoagulator (Fig. 1) with the following design parameters: height - 1 meter, length - 1 meter, width - 0.5 meters; power supply - MEAN WELL10A-24V.

Characteristics of the electrocoagulator:

- weight - $40 \mathrm{~kg}$;

- productivity - 72 liters / hour;

- automation - all technological processes are automated in real time;

- at the outlet from the installation - water in accordance with standards and recycled filtrate;

- the basic indicator for the technological processes of water treatment - $1 \mathrm{~kW}$ per $1 \mathrm{~m} 3$ of treatment (taking into account the operation of pumping equipment - $2-2.5 \mathrm{~kW}$ per $1 \mathrm{~m} 3$ );

- service personnel - 1 person per shift (regulations as for a sewage pumping station);

- power supply - $220 \mathrm{~V}, 50 \mathrm{~Hz}$.

Thus, the electrotechnological complex will consist of:

- electroflotator (anode - graphite, cathode - stainless steel), it allows the removal of suspended particles as a result of their interaction with the gases obtained in the process of electroflotation; effluent quality indicators affected by the module are the suspended particles, ammonium nitrogen, phosphorus.

- electrocoagulator, it performs electrolytic treatment of water in an electric field under the action of direct electric current with simultaneous production of coagulant (anodic dissolution of metal shavings of the Steel 3 brand when using stainless steel as a cathode); the quality indicators of effluents affected by the module are suspended particles, ammonium nitrogen, phosphorus, chlorides (insignificant effect).

- filter with floating expanded polystyrene loading, it removes suspended particles and flocs from pre-treated water (physically simulates the processes of reaction product separation obtained by electroflotocoagulation of aqueous solutions: sedimentation, hydrocycloning, etc.).

- To implement the study of chloride removal (the second stage of counteraction to the emergency) we developed a set of electrodializer, where the anode material - oxideruthenium-titanium anode (ORTA); cathode - stainless steel; cases are made of dielectric plastic; power supply MEAN WELL-10A-24V. Inter-electrode distance - $3 \mathrm{~mm}$; volume of treated water - 1.5 liters. Ion-selective membrane material is NM-MBR-1520. The principle of operation is a closed bypass circulation circuit.

- Characteristics of the electrodialyzer:

- - weight - $10 \mathrm{~kg}$;

- - productivity along the desalination path (at $p=0.35$ MPa) - 140 liters / hour;

- - the number of desalination working chambers - 5 pieces;

- - type of chamber laying - labyrinth-mesh;

- - the desalination degree for 1 water passage - 40-50\%;

- - water pressure at the inlet to the apparatus - 0.2-0.35 $\mathrm{MPa}$;

- - power supply - $220 \mathrm{~V}, 50 \mathrm{~Hz}$.

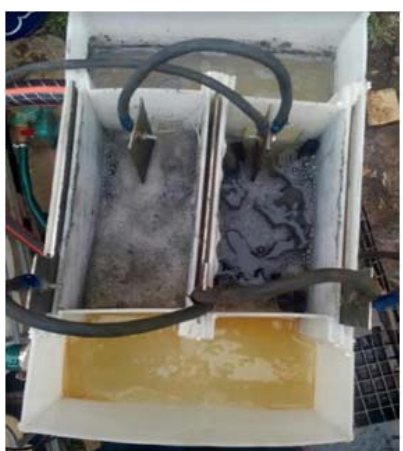

Fig. 1. Appearance of the electroflotocoagulator for sewage treatment of the meat-processing enterprise (experiments were carried out directly at the enterprise)

\section{Experimental research and analysis of their results}

Methods for assessing the quality of electroflotocoagulation wastewater treatment of meat processing plant (Fig. 2):

1. Samples of discharged water were taken from the sewerage system of the enterprise in front of the treatment facilities; the analysis of its quality indicators was carried out by express methods in the laboratory of the enterprise.

2. Contaminants were added (in order to simulate volley increases in their concentrations - the potential effect of emergencies).

3. Model water was purified by a single pass of the selected wastewater sample through the physical models of technological equipment in the following sequence: "electroflotocoagulator $\rightarrow$ filter". Moreover, the values of current and voltage were raised on the power supply to obtain the values of the concentration of pollutants according to the MPC (except for chlorides, for which the standard value is not more than $350 \mathrm{mg} / \mathrm{I}$ ).

4. The quality indicators analysis of the treated sewage is carried out in the accredited laboratory.

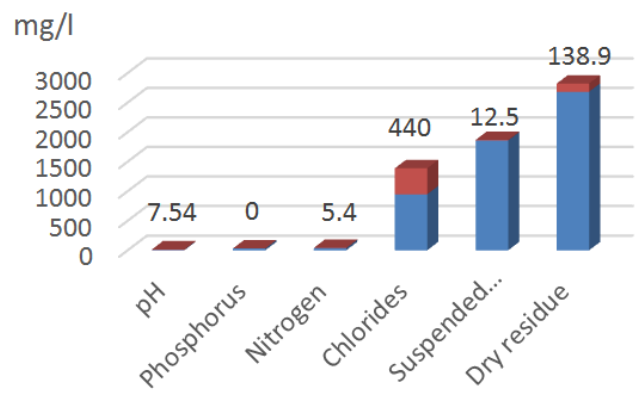

Fig. 2. Results of combined electrotechnological wastewater treatment of a meat processing enterprise (the first in a pair of columns - before treatment; the second in a pair of columns - after treatment)

After passing the effluent through physical models, the following was obtained: water with quality parameters that do not exceed the MPC (except for the indicator "chloride concentration"), sludge with a moisture content of $80 \%$. Resource costs were estimated according to the regime of electrotechnological purification, in which the normative quality indicators were achieved (Table 1).

Table 1. Energy resource parameters of combined electrotechnological wastewater treatment of a meat processing plant

\begin{tabular}{|l|l|l|l|}
\hline No & \multicolumn{1}{|c|}{ Resource } & \multicolumn{1}{c|}{ cost } & \multicolumn{1}{c|}{ Unit } \\
\hline 1. & Electricity & $8,05-14,95$ & $\mathrm{~kW}$ \\
& & $193,2-358,8$ & $\mathrm{~kW} \cdot$ day \\
& & $5796,0-10764,0$ & $\mathrm{~kW} \cdot$ month \\
\hline 2. & Metal & $2,345-4,355$ & $\mathrm{~kg} /$ hour \\
& shavings & $56,28-104,52$ & $\mathrm{~kg} /$ day \\
& (Steel 3) & $1688,4-3135,6$ & $\mathrm{~kg} /$ month \\
\hline
\end{tabular}


A separate analysis of electrotechnologically treated effluents (see Fig. 3) was carried out on important for the operation modes of electrodialysis indicators of the aqueous solutions composition [13], the results of which established their acceptable values: oxidation - not more than $5 \mathrm{mgO}_{2} /$ $\mathrm{dm}^{3}$ (ISO 11885); concentration of suspended particles - no more than $2 \mathrm{mg} / \mathrm{dm}^{3}$; total concentration of total iron and manganese - not more than $0.05 \mathrm{mg} / \mathrm{dm}^{3}$ (ISO 11885).
Based on the confirmed efficiency of wastewater treatment in the first stage of emergency response for meat processing plants (see Fig. 3) the further research was carried out on real effluents of dairy, bakery, alcohol and sugar companies. Evaluation of wastewater indicators "Concentration of chlorides" and "COD" before and after treatment was done in an accredited laboratory for the composition analysis of aqueous solutions.

As a result of experimental researches the necessary quality of clearing was reached (tab. 2).

Table 2. The experimental treatment results of real wastewater from food enterprises

\begin{tabular}{|c|c|c|c|c|c|c|}
\hline \multirow{2}{*}{ Spillway object } & \multicolumn{2}{|c|}{ Sewage (before treatment) } & \multicolumn{2}{|c|}{$\begin{array}{l}\text { After electroflotocoagulation } \\
\text { treatment }\end{array}$} & \multicolumn{2}{|c|}{ After electrodialysis treatment } \\
\hline & $\begin{array}{c}\text { Chlorides, } \\
\mathrm{mg} / \mathrm{I}\end{array}$ & $\begin{array}{l}\mathrm{COD} \\
\mathrm{mgO}_{2} / \mathrm{I}\end{array}$ & $\begin{array}{c}\text { Chlorides, } \\
\mathrm{mg} / \mathrm{l}\end{array}$ & $\begin{array}{c}\mathrm{COD} \\
\mathrm{mgO}_{2} / \mathrm{I}\end{array}$ & $\begin{array}{c}\text { Chlorides, } \\
\mathrm{mg} / \mathrm{I}\end{array}$ & $\begin{array}{c}\mathrm{COD} \\
\mathrm{mgO}_{2} / \mathrm{I}\end{array}$ \\
\hline milk plant & 780 & 2654 & 1523 & 432 & 144 & 17 \\
\hline bread-baking plant & 304 & 467 & 304 & 96 & 136 & 12 \\
\hline distillery plant & 437 & 1673 & 642 & 123 & 113 & 16 \\
\hline sugar plant & 567 & 2410 & 708 & 83 & 127 & 10 \\
\hline
\end{tabular}

Note: according to the data of the accredited wastewater quality laboratory, the uncertainties of type $\mathrm{B}$ measurement of quality parameters are expanded $(P=0.95)$ : chlorides $- \pm 4.5 \%$, COD $- \pm 5.5 \%$

The conducted research allowed to establish the acceptability of the proposed two-stage approach to emergency response and to determine the energy consumption for the operation of electrodialysis equipment (Fig. 3).

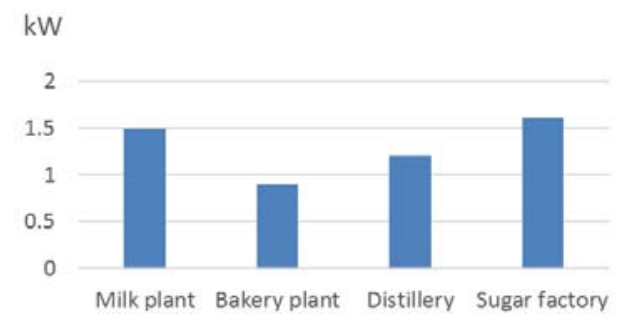

Fig. 3. Energy consumption for purification $1 \mathrm{~m}^{3}$ to the MPC according to the parameter "Concentration of chlorides" (simulation of emergency response at food enterprises)

Taking into account the expanded measurement uncertainty type $\mathrm{B}$, the expression for the establishment of general energy consumption to counter emergency situations will look like:

(1) Energy consumption $=(E \pm E U) \quad H O, k W$,

where $E$ is energy consumption for purification $1 \mathrm{~m}^{3}$ to MPC (electroflotocoagulation and electrodialysis), $\mathrm{kW} / \mathrm{m}^{3}, E U$ is extended uncertainty of type B measurements, $\mathrm{HO}$ is the total volume of volley emissions (raw materials contained in technological tanks and aqueous solutions of production processes), which must be cleaned in case of an emergency, $\mathrm{m}^{3}$

Then on the basis of experimental researches we received the following analytical dependences: for milk plants:

(2) Energy consumption $=(1,42 \div 1,57) \quad \mathrm{HO}, \mathrm{kW}$

for bread-baking plants:

(3) Energy consumption $=(0,86 \div 0,94) \quad \mathrm{HO}, \mathrm{kW}$

for distillery plants:

(4) Energy consumption $=(1,15 \div 1,25) \quad \mathrm{HO}, \mathrm{kW}$

for sugar plants:

\section{(5) Energy consumption $=(1,53 \div 1,67) \quad \mathrm{HO}, \mathrm{kW}$}

After analyzing the technological lines and possible volumes of volley emissions in the form of raw materials contained in technological tanks and aqueous solutions used in the production processes of food enterprises, we set the minimum and maximum volumes of effluents to be treated in case of emergency (Table 3, Fig. 4).

Table 3. Sewage volumes to be treated in the event of an emergency

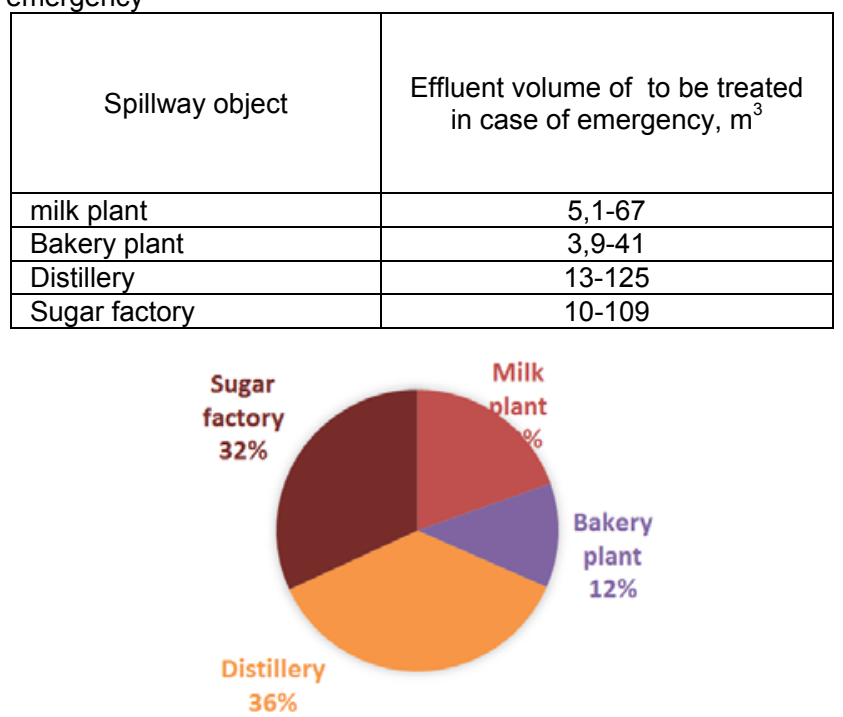

Fig. 4. Comparative estimate of the wastewater maximum possible volumes in emergencies' case in food production

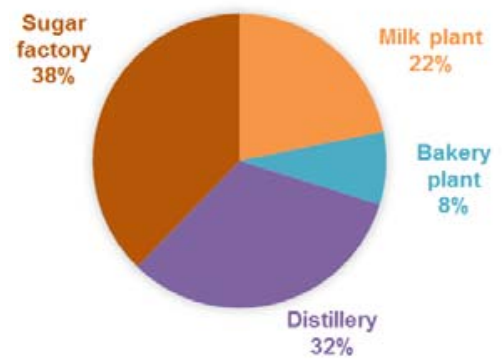

Fig. 5. Comparative estimate of total energy consumption at the emissions' maximum volume and the inclusion of the disposal unit in an emergency

To compare the energy and economic performance of electrical systems to combat emergencies, depending on the type of enterprise and the volume of wastewater, we calculate the maximum costs in case of emergencies (Fig.5).

In case of exceeding the level of pollutants in the wastewater of enterprises discharged into the sewerage 
system, compared to the local Rules of acceptance, enterprises pay fines that are ten times higher than the calculated financial costs in the case of using the emergency response unit, which also confirms technical economic expediency of the studied electrotechnological complex (Fig. 6).

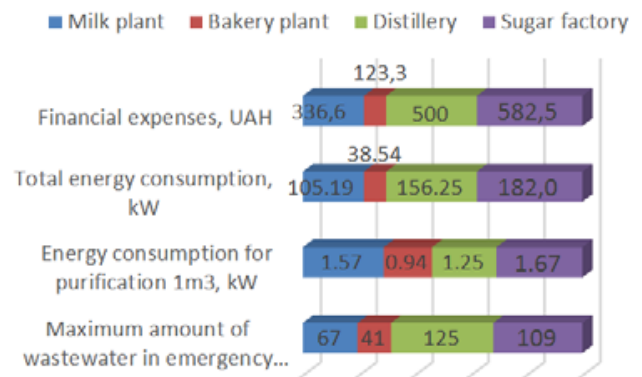

$0 \% \quad 20 \% 40 \%$ 60\% $80 \% 100 \%$

Fig. 6. Comparative estimate of maximum costs in the case of using the emergency response unit.

In this case, in the event of an emergency (especially potentially catastrophic) it is necessary to transfer additional information to the highest hierarchical level of the control unit (Fig. 7) regarding the estimated concentrations of pollutants that may enter wastewater from technological processes.

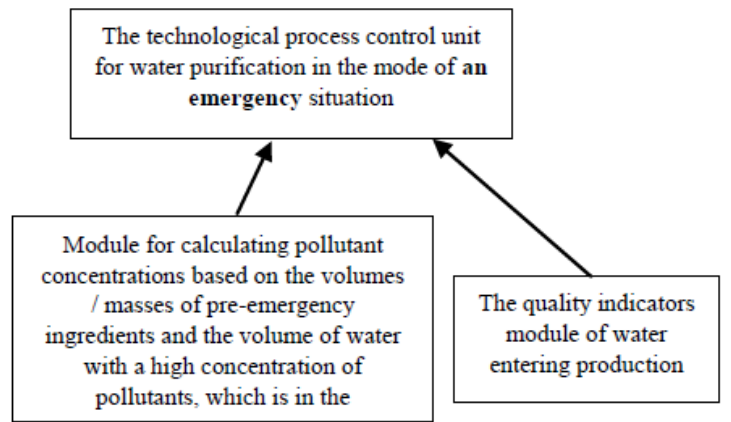

Fig.7. The submission structure for additional information to the water treatment control unit (emergency mode)

The use of such a structure (see Fig. 7) will allow more efficient and reliable operation of electrical complex dialyzers, as it will provide: increase the efficiency of treatment on the elements of major treatment plants (eg, electroflotocoagulation) and calculate the modes of electrodializers to get them highly concentrated effluents.

\section{Conclusions}

1. In order to ensure effective counteraction to emergency situations in food production through the "spillway" channel, it is necessary to: provide for the possibility of operative increase of reagents and other resources at the main treatment facilities in emergency cases; to include in the scheme of water treatment the block of highly concentrated drains processing, having applied, for example, electrotechnical complex of an electrodializer as this block

2. Penalties paid by enterprises in case of exceeding the pollutant levels in wastewater are times higher than the calculated financial costs in case of using the emergency response unit, which also confirms the technical and economic feasibility of the studied electrical complex.

3. Further research to combat emergencies in food production should be aimed at creating methodological support for forecasting the consequences of pollutant volley emissions and, accordingly, setting the parameters of the water treatment electrotechnological unit and prevention of catastrophic consequences.
Authors: Nataliia Zaiets, doctor of engineering sciences, professor of department of Automation and Robotic Systems, National University of Life and Environmental Sciences of Ukraine, Geroev Oboroni str., 12, Kyiv, 03041, Ukraine, E-mail: z-n@ukr.net; Volodimir Shtepa, doctor of engineering sciences, associate professor of the department of Higher Mathematics and Information Technologies, Polessky State University, Dneprovskoy flotilii, 23, Pinsk, 225710, Republic of Belarus, E-mail: shns1981@gmail.com; Ihor Kondratenko, doctor of engineering sciences, corresponding member of the NAS of Ukraine, head of the department of electromagnetic systems of the Institute of Electrodynamics of the NAS of Ukraine, prospekt Peremogy, 56, Kiev, 03680, Ukraine, Email: dep7ied@ukr.net; Andrii Zhyltsov, doctor of engineering sciences, professor and head of department of electrical engineering, electromechanics and electrotechnology, National University of Life and Environmental Sciences of Ukraine, Geroev Oboroni str., 15, Kyiv, 03041, Ukraine, E-mail: azhilt@gmail.com; Andrii Rogovik, graduate student of department Automation and computer technology control systems, National University of Food Technologies, Kyiv, Volodymyrska str., 68, 01601, Ukraine, E-mail: andrey_rogovik@ukr.net

\section{REFERENCES}

[1] Mazorenko D.I., Tsapko V.G., Goncharov F.I. Engineering ecology of agricultural production. K .: Znannia, 2006. 376 p.

[2] Yaromsky V.N. Treatment of wastewater from food and processing enterprises. Minsk: BSU Publishing Center. 2009. $171 \mathrm{p}$.

[3] Shtepa V.M., Goncharov F.I., Syrovatka M.A. Substantiation and development of the energy efficiency criterion for electrotechnological water treatment systems functioning. Scientific Bulletin of the National University of Life and Environmental Sciences of Ukraine. Series: Engineering and energy of agro-industrial complex: a collection of scientific works. Kyiv: NUBiPU. 2011. Issue. 161. P. 187-193.

[4] Chebotaeva M.V. BIOMAR $®$ treatment plants in the beverage industry in Russia. Beer and Drinks. 2008. No 4. P. 44-45.

[5] Schuster K. B \& S-DAF technology of pressure flotation. Ecology of production. 2007. No 4. P. 1-4.

[6] Eboule P. S. Pouabe, Hasan Ali N.. Accurate Fault Detection and Location in Power Transmission Line Using Concurrent Neuro Fuzzy Technique. Przegląd Elektrotechniczny. No 1. 2021. P. 37-45.

[7] Swolkień J., Tomaszek M., Halecki W.. Zastosowanie inteligentnych sieci czujników i systemów monitorowania do zarządzania gospodarka wodno-kanalizacyjna w obszarach zurbanizowanych. Przegląd Elektrotechniczny. No 2. 2021. P. $142-148$.

[8] Zaiets N., Vlasenko L., Lutskaya N., Usenko S. System Modeling for Construction of the Diagnostic Subsystem of the Integrated Automated Control System for the Technological Complex of Food Industries, Proceedings 3rd International Conference on Mechatronics Systems and Control Engineering (ICMSCE), Nice, France, February 26-28, 2019., p.105-110.

[9] Zaiets N., Shtepa V., Pavlov P., Elperin I., Hachkovska M., Development of a resource-process approach to increasing the efficiency of electrical equipment for food production, EasternEuropean Journal of Enterprise Technologie, 2019, 5(8), pp. $59-65$.

[10] Goncharov F., Shtepa V. Methodology for improving the environmental safety of agro-industrial and food industries. Technical and technological aspects of development and testing of new equipment and technologies for agriculture of Ukraine. 2012. No 16 (30). Tom 2. P. 97-10.

[11]Analytical review of water purification methods. URL: http://aquaros.ru/analiticheskiy-obzor-metodov-ochistki-vody.

[12] Chao Y., Liang T. A feasibility study of industrial wastewater recovery using electro dialysis reversal. Desalination. 2008. Vol. 221. No 3. P. 433-439.

[13]Zaiets N. A., Shtepa V. M. Systematization of water purification electro-technological complexes for grub wines. Power engineering and automation. 2018. No. 4. P. 49-62. Access mode to article: http://journals.nubip.edu.ua /index.php/Energiya/article/view/11554 


\title{
PRZEGLĄD ELEKTROTECHNICZNY Vol 2021, No 9
}

\author{
Contents
}

Marcin BASZYŃSKI, Kacper SOWA, Stanisław PIRÓG - An active power filter with energy storage for power surge compensation- energy balance and practical implementation - Part 1

Marcin BASZYŃSKI, Kacper SOWA, Stanisław PIRÓG - An active power filter with energy storage for power surge compensation- energy balance and practical implementation - Part 2

Grażyna FRYDRYCHOWICZ-JASTRZĘBSKA, Dorota BUGAŁA - Hybrid towers of wind turbines - alternative energy storage concept

Mateusz MIKOŁAJCZYK,' Anita MIKOŁAJCZYK - The influence of different luminous fluxes from halogen and LED lamps on the intensity of photosynthesis in the presence of ascorbic acid

Vasyl V. KUKHARCHUK, Sergii V. PAVLOV, Samoil Sh. KATSYV, Andrii M. KOVAL,,Volodymyr S. HOLODIUK, Mykhailo V. LYSYI, Andrzej KOTYRA, Orken MAMYRBAEV, Aidana KALABAYEVA - Transient analysis in 1st order electrical circuits in violation of commutation laws

Karina G. SELIVANOVA, Oleg G. AVRUNIN, Maksym Y. TYMKOVYCH, Tamila V. MANHORA, Oleh S. BEZVERKHYI, Zbigniew OMIOTEK, Aliya KALIZHANOVA, Ainur KOZBAKOVA - "3D visualization of human body internal structures surface during stereo-endoscopic operations using computer vision techniques

7 Sergey VYATKIN, Tetiana KOROBEINIKOVA, Pavlo MYKHAYLOV, Roman CHEKHMESTRUK, Oksana VODZINSKA, VasyI OVCHARUK, Andrzej KOTYRA, Gulzhan KASHAGANOVA, Zhazira JULAYEVA - A method for calculating trajectories independent of the explicit determination of an object's equation of motion Volodymyr DUBOVOI, Maria S. YUKHIMCHUK, Nelya M. KYRYLENKO, Andrii H. BUKHUN, Olena M. HOMONYUK, Maksat KALIMOLDAYEV, Konrad GROMASZEK, Saule SMAILOVA - Functional safety assessment of one-level coordination of distributed cyber-physical objects

Andriy P. OLIYNYK, Lidiia I. FESHANYCH, Irina M. USHKALENKO, Andrzej SMOLARZ, Galim KALIMBETOV, Marzhan SPABEKOVA - Optimal anti-surge control of gas pumping unit with gas turbine drive

Volodymyr Ya. HALCHENKO, Ruslana TREMBOVETSKA, Volodymyr TYCHKOV, Mykyta SAPOGOV, Konrad GROMASZEK, Saule SMAILOVA, Saule LUGANSKAYA - Additive neural network approximation of multidimensional response surfaces for synthesis of eddy-current probes

Vladislav KUCHANSKYY, Denys MALAKHATKA, Viktoria DUMENKO, Piotr KISAŁA, Nataliya DENISSOVA, Bakhyt YERALIYEVA - Assessment of the phase-by-phase transmission line effect asymmetry on power transfer capability in open phase mode

2 Waldemar WOJCIK, Zinovii NYTREBYCH, Oksana MALANCHUK, Maria VISTAK, Liubov KRAVCHENKO, Bogdan PINAEV, Saule RAKHMETULLINA, Ainur TOIGOZHINOVA - Modelling of the processes in electrical systems by two-point problem for nonhomogeneous telegraph equation

Piotr KUBISZYN - Guardband methods used to evaluate the results of digital multimeters calibration on the example of FLUKE MET/CAL software

Magdalena NIZIOK - - Simulation tests of the phase method for measurements of the time delay of random signals Rafał CHORZĘPA - Application of conditional averaging to assess the uncertainty of the arithmetic mean of random signals

Rafael GIVANILDO, Denis LIMA, Paulo PARIS, Emerson PEDRINO - Low-Cost and Accuracy Smart Meter Prototype for Smart Grids

Mahmood T. Alkhayyat, Mohammed Y. Suliman, Faisal Falah Aiwa - PQ \& DQ Based Shunt Active Power Filter with PWM \& Hysteresis Techniques

Najwan WAISI, Nawal ABDULLAH, Mohammed GHAZAL - The Automatic Detection of Underage Troopers from Live-Videos Based on Deep Learning

Tan Rui Lin, Nur Hanisah Omar Khan, Muhamad Zalani Daud - Arduino based Appliance Monitoring System using SCT-013 Current and ZMPT101B Voltage Sensors

Nahla TOUATI, Imen SAIDI - Internal Model Control for Underactuated Systems based on Novel Virtual Inputs Method Adnane MOUFFAK - An Optimal Design of Non-Causal Recursive Digital Filters with Zero Phase Shift using Chebyshev approximation and Linear Programming

Natalia ZAIETS, Volodymyr SHTEPA, Ihor KONDRATENKO, Andrii ZHYLTSOV, Andrii ROHOVIK - The use of electrotechnical equipment for food production wastewater treatment

3 Stanilav S. Girshin, Aleksandr AY. Bigun, Nikolay A. Mel'nikov, Elena V. Petrova, Vladislav M. Trotsenko, Dmitry S. Osipov, Vladimir N. Goryunov - Loss of energy in electrical networks with capacitor banks under optimal reactive power control

Chiraphon TAKEANG, Apinan AURASOPON - A New Hybrid Algorithm combining Ant Lion Optimization and Particle Swarm Optimization to Solve an Economic Dispatch Problem with non-smooth cost function

Mohammad Abu Sarhan, Andrzej Bień, Szymon Barczentewicz, Rana Hassan - A Review of Electricity and Renewable Energy Sectors Status and Prospect in Jordan

Sudhakiran Ponnuru, Ashok Kumar R, Jothi Swaroopan NM - Switching Strategies of Single Stage Battery based Microgrid

Mr. Tiabur Rahman Tamim Sk. Shariful Alam, Mr. Amanullah Asraf - An Enhancement in Accuracy of Vehicle Detection in Parking Areas Employing Haar-Like Features and AdaBoost Algorithm

Mustafa Hussein Ibrahim, Muhammed A Ibrahim - Solar-Wind Hybrid Power System Analysis Using Homer for Duhok, Iraq

Sławomir BARAŃSKI, Piotr BŁASZCZYK - Automatic train protection - ATP system

Jerzy HICKIEWICZ, Piotr RATAJ, Przemysław SADŁOWSKI ${ }^{-}$The 1st Congress of
June 1919 in Warsaw. Establishment of the Association of Polish Electrical Engineers 


\title{
PRZEGLAD ELEKTROTECHNICZNY Vol 2021, Nr 9
}

\author{
Spis treści
}

01 Marcin BASZYŃSKI, Kacper SOWA, Stanisław PIRÓG - Filtr aktywny z dodatkowym zasobnikiem energii do kompensacji wahań moc czynnej - bilans energetyczny oraz praktyczna implementacja - część 1

02 Marcin BASZYŃSKI, Kacper SOWA, Stanisław PIRÓG - - Filtr aktywny z dodatkowym zasobnikiem energii do kompensacji wahań moc czynnej - bilans energetyczny oraz praktyczna implementacja - część 2

03 Grażyna FRYDRYCHOWICZ-JASTRZĘBSKA, Dorota BUGAŁA - Wieże hybrydowe turbin wiatrowych - alternatywną koncepcją magazynowania energii

04 Mateusz MIKOŁAJCZYK,' Anita MIKOŁAJCZYK - Wpływ różnych strumieni świetlnych pochodzących z lamp halogenowych i ledowych na intensywność fotosyntezy w obecności kwasu askorbinowego

05 Vasyl V. KUKHARCHUK, Sergii V. PAVLOV, Samoil Sh. KATSYV, Andrii M. KOVAL,,Volodymyr S. HOLODIUK, Mykhailo V. LYSYI, Andrzej KOTYRA, Orken MAMYRBAEV, Aidana KALABAYEVA - Analiza stanów przejściowych w obwodach elektrycznych 1 rzędu z naruszeniem praw komutacji

06 Karina G. SELIVANOVA, Oleg G. AVRUNIN, Maksym Y. TYMKOVYCH, Tamila V. MANHORA, Oleh S. BEZVERKHYI, Zbigniew OMIOTEK, Aliya KALIZHANOVA, Ainur KOZBAKOVA - "Etapy wizualizacji powierzchni struktur wewnętrznych ciała ludzkiego podczas operacji stereo-endoskopowych i laparoskopowych

07 Sergey VYATKIN, Tetiana KOROBEINIKOVA, Pavlo MYKHAYLOV, Roman CHEKHMESTRUK, Oksana VODZINSKA, Vasyl OVCHARUK, Andrzej KOTYRA, Gulzhan KASHAGANOVA, Zhazira JULAYEVA - Metoda obliczania trajektorii niezależnie od jednoznacznego wyznaczania równania ruchu obiektu

08 Volodymyr DUBOVOI, Maria S. YUKHIMCHUK, Nelya M. KYRYLENKO, Andrii H. BUKHUN, Olena M. HOMONYUK, Maksat KALIMOLDAYEV, Konrad GROMASZEK, Saule SMAILOVA - Ocena bezpieczeństwa funkcjonalnego jednopoziomowej koordynacji rozproszonych obiektów cyber-fizycznych

09 Andriy P. OLIYNYK, Lidiia I. FESHANYCH, Irina M. USHKALENKO, Andrzej SMOLARZ, Galim KALIMBETOV, Marzhan SPABEKOVA - Optymalne sterowanie przeciwpompażowe gazowym zespołem pompowym z napędem turbinowym

10 Volodymyr Ya. HALCHENKO, Ruslana TREMBOVETSKA, Volodymyr TYCHKOV, Mykyta SAPOGOV, Konrad GROMASZEK, Saule SMAILOVA, Saule LUGANSKAYA - Aproksymacja wielowymiarowych powierzchni odpowiedzi za pomocą addytywnych sieci neuronowych do syntezy sond wiroprądowych

11 Vladislav KUCHANSKYY, Denys MALAKHATKA, Viktoria DUMENKO, Piotr KISAŁA, Nataliya DENISSOVA, Bakhyt YERALIYEVA - Ocena wpływu asymetrii międzyfazowej linii przesyłowej na zdolność przesyłu mocy przy braku jednej fazy

12 Waldemar WOJCIK, Zinovii NYTREBYCH, Oksana MALANCHUK, Maria VISTAK, Liubov KRAVCHENKO, Bogdan PINAEV, Saule RAKHMETULLINA, Ainur TOIGOZHINOVA - Modelowanie procesów w systemach elektrycznych za pomocą problemu dwupunktowego dla niejednorodnego równania

13 Piotr KUBISZYN - Metody pasma ochronnego stosowane do oceny wyników wzorcowania multimetrów cyfrowych na przykładzie oprogramowania FLUKE MET/CAL

14 Magdalena NIZIOt - - Badania symulacyjne fazowej metody pomiaru opóźnienia sygnałów losowych

15 Rafał CHORZĘPA - Zastosowanie warunkowego uśredniania do oceny niepewności średniej arytmetycznej sygnałów losowych

16 Rafael GIVANILDO, Denis LIMA, Paulo PARIS, Emerson PEDRINO - Tani i dokładny prototyp inteligentnego licznika dla inteligentnych siec

17 Mahmood T. Alkhayyat, Mohammed Y. Suliman, Faisal Falah Aiwa - Bocznikowy aktywny filtr mocy oparty na PQ i DQ z technikami PWM i histerezy

18 Najwan WAISI, Nawal ABDULLAH, Mohammed GHAZAL - Automatyczne wykrywanie nieletnich żołnierzy z wideo na żywo w oparciu o metodę Deep Learning

19 Tan Rui Lin, Nur Hanisah Omar Khan, Muhamad Zalani Daud - System monitorowania poboru mocy oparty na Arduino za pomocą czujników prądu SCT-013 i napięcia ZMPT101B

20 Nahla TOUATI, Imen SAIDI - Kontrola modelu wewnętrznego dla systemów niedostatecznie aktywowanych w oparciu o nową metodę wirtualnych wejść

21 Adnane MOUFFAK - Optymalna procedura projektowania nieprzyczynowych rekurencyjnych filtrów cyfrowych z zerowym przesunięciem fazowym przy użyciu przybliżenia Czebyszewa i programowania liniowego

22 Natalia ZAIETS, Volodymyr SHTEPA, Ihor KONDRATENKO, Andrii ZHYLTSOV, Andrii ROHOVIK - Wykorzystanie urządzeń elektrycznych do oczyszczania ścieków z produkcji spożywczej

23 Stanilav S. Girshin, Aleksandr AY. Bigun, Nikolay A. Mel'nikov, Elena V. Petrova, Vladislav M. Trotsenko, Dmitry S. Osipov, Vladimir N. Goryunov - Straty energii w sieciach elektrycznych z bateriami kondensatorów przy optymalnej kontroli mocy biernej

24 Chiraphon TAKEANG, Apinan AURASOPON - Nowy algorytm hybrydowy łączący optymalizację Ant Lion i optymalizację roju cząstek w celu rozwiązania ekonomicznego problemu dystrybucji z funkcją kosztów nierównomiernych

25 Mohammad Abu Sarhan, Andrzej Bień, Szymon Barczentewicz, Rana Hassan - Przegląd systemu energetycznego oraz sektoru energii odnawialnej w Jordani

26 Sudhakiran Ponnuru, Ashok Kumar R, Jothi Swaroopan NM - Strategie przełączania mikrosieci opartej na baterii jednoetapowej

27 Mr. Tiabur Rahman Tamim Sk. Shariful Alam, Mr. Amanullah Asraf - Zwiększenie dokładności wykrywania pojazdów na parkingach dzięki funkcjom podobnym do algorytmu Haar i AdaBoost

28 Mustafa Hussein Ibrahim, Muhammed A Ibrahim - Solar- Analiza hybrydowego systemu zasilania energią słoneczno-wiatrową przy użyciu Homera dla Duhok, Irak

29 Sławomir BARAŃSKI, Piotr BŁASZCZYK - Automatyczne ograniczanie prędkości pociągu - system AOP

30 Jerzy HICKIEWICZ, Piotr RATAJ, Przemysław SADŁOWSKI`I Zjazd Elektrotechników Polskich 7-9 czerwca 1919 roku w Warszawie. Utworzenie Stowarzyszenia Elektrotechników Polskich 